\title{
Papers
}

\section{Prevalence of Helicobacter pylori in patients with gastro-oesophageal reflux disease: systematic review}

\author{
Anan Raghunath, A Pali S Hungin, David Wooff, Susan Childs
}

\begin{abstract}
Objectives To ascertain the prevalence of Helicobacter pylori in patients with gastro-oesophageal reflux disease and its association with the disease.

Design Systematic review of studies reporting the prevalence of $H$ pylor $i$ in patients with and without gastro-oesophageal reflux disease.

Data sources Four electronic databases, searched to November 2001, experts, pharmaceutical companies, and journals.

Main outcome measure Odds ratio for prevalence of $H$ pylor $i$ in patients with gastro-oesophageal reflux disease.

Results 20 studies were included. The pooled estimate of the odds ratio for prevalence of $\mathrm{H}$ pylori was $0.60(95 \%$ confidence interval 0.47 to 0.78$)$, indicating a lower prevalence in patients with gastro-oesophageal reflux disease. Substantial heterogeneity was observed between studies. Location seemed to be an important factor, with a much lower prevalence of $H$ pylor $i$ in patients with gastro-oesophageal reflux disease in studies from the Far East, despite a higher overall prevalence of infection than western Europe and North America. Year of study was not a source of heterogeneity. Conclusion The prevalence of $H$ pylori infection was significantly lower in patients with than without gastro-oesophageal reflux, with geographical location being a strong contributor to the heterogeneity between studies. Patients from the Far East with reflux disease had a lower prevalence of $H$ pylor $i$ infection than patients from western Europe and North America, despite a higher prevalence in the general population.
\end{abstract}

\section{Introduction}

Gastro-oesophageal reflux disease is a common condition affecting $25-40 \%$ of the population. ${ }^{1}$ It is managed mainly in primary care and is associated with the largest prescribing cost in the NHS. ${ }^{2}$ Although there is good evidence that infection with $H$ pylor $i$ is the principal cause of peptic ulcer disease, there is uncertainty about the organism's role in gastro-oesophageal reflux disease. Treating $H$ pylori infection is effective in healing duodenal ulcers. ${ }^{3}$ The effect of eradication of the organism in patients with gastro-oesophageal reflux disease is less clear, with some reports suggesting that this might be counterproductive and that $H$ pylori infection might protect against the disease. ${ }^{45}$ However, the recent Maastricht 2 guidelines on the management of patients with $H$ pylori infection recommend eradication in those with gastrooesophageal reflux disease who are likely to require long term proton pump inhibitor therapy. ${ }^{6}$ This is because profound acid suppression may accelerate the progression of $H$ pylori induced atrophic gastritis, increasing the potential risk of cancer.

The evidence for an association between $H$ pylori and gastro-oesophageal reflux disease remains mixed and largely uncertain. Studies evaluating the presence or absence of $H$ pylori on gastro-oesophageal reflux disease have often had drawbacks in design and have given conflicting results. ${ }^{78}$ Fundamentally it is not certain whether there are differences in the prevalence of $H$ pylori between patients with and without gastrooesophageal reflux disease. ${ }^{9-13}$

We conducted a systematic review to establish the overall prevalence of $H$ pylori in patients with gastro-oesophageal reflux disease and to determine if this is significantly different from patients without the disease. This is important for determining if patients with the disease differ and to quantify the extent of infection. This topic is also of relevance because of the large numbers of patients in the community taking long term proton pump inhibitors, mostly for reflux. The determination of $H$ pylori status in these patients has so far not been a clinical issue; gastro-oesophageal reflux disease is commonly diagnosed and treated in primary care on the basis of a clinical history alone.

\section{Methods}

We included studies to November 2001 fulfilling certain eligibility criteria (box) by searching Medline, Embase, Cinahl, and Cochrane, using subject terms and text words. Bibliographies of retrieved studies were reviewed, experts in six countries and pharmaceutical companies contacted (see bmj.com), and general medical and major gastroenterology journals searched over the previous year.

\section{Assessment of eligibility and trial quality}

Gastro-oesophageal reflux disease was defined according to published definitions. ${ }^{14-17}$ These comprised two categories, both in patients who had heartburn or reflux as the predominant symptoms. The first was the
Centre for Integrated Health Care Research, Wolfson Research Institute, University of Durham, Stockton on Tees TS17 6BH

Anan Raghunath honorary research fellow

A Pali S Hungin professor of primary care and general practice

Department of Mathematical Sciences, Statistics and Mathematics Consultancy Unit, University of Durham, Science Laboratories, Durham DH1 3LE David Wooff director

Information Management Research Institute School of Information Studies, University of Northumbria, Newcastle upon Tyne NE1 8ST Susan Childs research associate

Correspondence to: A Raghunath raghu@nath. freeserve.co.uk

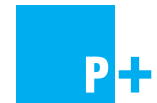

Details of the searches and tables of the excluded studies and prevalences appear on bmi.com 
presence of endoscopically defined oesophagitis and the second, when endoscopy did not show oesophagitis, a positive result for $\mathrm{pH}$ monitoring with or without oesophagitis on histology.

Two investigators independently reviewed the papers according to the predefined criteria (see box). Abstracts were included only if they met the eligibility criteria. Disagreements were resolved by consensus with a third reviewer. Quality assessments focused on whether the methods for obtaining cases and controls, data collection, and $H$ pylori testing were stated.

\section{Data extraction}

AR collated data from eligible studies on standardised forms, which were checked by SC. Data on the prevalence of $H$ pylor $i$ in various grades of oesophagitis and the absence of visible reflux disease on endoscopy were recorded as reported, but for analysis the overall

\section{Eligibility and quality criteria for inclusion in} systematic review

Studies with a comparator, control, or reference group

Patients with gastro-oesophageal reflux disease should have undergone gastroscopy.

- Included:

- Patients with endoscopically proved oesophagitis

- Patients with normal appearance of oesophagus on endoscopy and with confirmation of gastro-oesophageal reflux disease either by $\mathrm{pH}$ studies or histology

- Excluded:

- Patients with non-ulcer dyspepsia in whom other confirmation of gastro-oesophageal reflux disease by $\mathrm{pH}$ studies or histology of the oesophagus was not available

- Patients with normal endoscopy result and typical reflux symptoms but confirmation by $\mathrm{pH}$ studies or histology not available or confirmed

- Patients known or discovered to have Barrett's oesophagus

- Patients with confirmed peptic ulcer disease

- Patients who had received proton pump inhibitors within the previous two weeks or undergone eradication of $H$ pylori

Comparator group (one or more of the following)

- Normal endoscopy result and absence of symptoms of gastro-oesophageal reflux disease

- Healthy asymptomatic volunteers

- Absence of pathological reflux on $\mathrm{pH}$

monitoring - that is, oesophageal $\mathrm{pH}$ is $<4$ for more

than $3.5 \%$ of total recorded time, or as defined by

author of the study

- Normal endoscopy result and absence of oesophagitis on histology

\section{Quality criteria}

- Documentation of how cases were obtained

- Appropriateness of comparator

- Similar data collection for cases and comparator group

- Similar H pylori testing for cases and comparator group

- Basic data adequately described

- Statistical methods described and significance levels assessed prevalence of $H$ pylori in gastro-oesophageal reflux disease was used.

\section{Data synthesis}

Each of the 20 included studies was summarised according to its odds ratio, with an odds ratio of less than one indicating a higher prevalence of $H$ pylori among controls than among patients with gastrooesophageal reflux disease. Results were pooled with a fixed effect (Mantel-Haenszel) model, which was assessed with a test of homogeneity and a funnel plot. ${ }^{18}$ Odds ratios were pooled with a random effects model in cases of substantial heterogeneity. ${ }^{19}$ The statistical analysis was performed with the free package $\mathrm{R}$, and the rmeta subpackage contributed by Thomas Lumley (University of Washington). ${ }^{20}$

\section{Results}

Our initial search identified 654 articles, but only 45 evaluated the prevalence of $H$ pylori in patients with gastro-oesophageal reflux disease. Thirty seven of these met the eligibility criteria; 16 were excluded after further scrutiny (see table A on bmj.com), ${ }^{7}{ }^{13} 21-33$ and one was excluded because of overlap with a study by the same lead author (the proportions between the two studies were so close that there was virtually no difference in results; see table A on bmj.com). ${ }^{34}{ }^{35}$ This left 20 studies for review, totalling 4134 patients, of whom $58.5 \%(\mathrm{n}=2418)$ were in control groups (table). ${ }^{105-53}$

\section{Prevalence of $\boldsymbol{H}$ pylori infection}

The average prevalence of $H$ pylori infection in patients with gastro-oesophageal reflux disease was 38.2\% (range 20.0-82.0\%) compared with 49.5\% (29.0-75.6\%) in the comparator group. Four studies showed a higher prevalence of $H$ pylori infection among patients with gastro-oesophageal reflux disease, but not significantly so (fig 1 and table B on bmj.com). ${ }^{36}{ }^{46}{ }^{47}$ The remaining studies showed a lower prevalence among patients with gastro-oesophageal reflux disease, significantly so in six studies. ${ }^{1035424549}$ The pooled odds ratio was 0.58 (95\% confidence interval 0.51 to 0.66 ), indicating a lower prevalence of $H$ pylori infection among patients with gastro-oesophageal reflux disease (heterogeneity test: $\chi^{2}=83.01, \mathrm{df}=19, \mathrm{P}<0.001$ )

We found no clear evidence of publication bias (fig 2): nor would any be expected in this context. Because of the presence of substantial heterogeneity, the studies were pooled with the DerSimonian-Laird random effects model (summary odds ratio $0.60,0.47$ to 0.78 ), which showed weaker but still strong evidence of a lower prevalence of $H$ pylori infection among patients with gastro-oesophageal reflux disease.

Statistical heterogeneity was investigated by year of study (no effect) and by location. Five studies were of patients from the Far East, ${ }^{35} 42454953$ seven of patients from North America, ${ }^{37} 384048$ 50-52 and seven of patients from western Europe. ${ }^{10} 404244454748$ One further study originated from Chile. ${ }^{36}$ Some similarities were found in results for studies from particular geographical locations (fig 1). When the three main groups were analysed separately, the results for western Europe gave an odds ratio of 0.76 (0.61 to 0.96$)$ and a test for heterogeneity of $\chi^{2}=14.01, \mathrm{df}=6, \mathrm{P}=0.030$. One study seemed to dominate the analysis, but repeating the analysis after excluding this study gave an odds ratio of 


\begin{tabular}{|c|c|c|c|c|c|}
\hline \multicolumn{6}{|c|}{ Studies included in systematic review } \\
\hline Reference & Type of study & Participants & Intervention & Outcome & Comments or conclusions \\
\hline $\begin{array}{l}\text { Werdmuller and } \\
\text { Loffeld } 1997^{10}\end{array}$ & $\begin{array}{l}\text { Descriptive, } \\
\text { prospective }\end{array}$ & $\begin{array}{l}\text { Consecutive patients undergoing } \\
\text { endoscopy of upper gastrointestinal } \\
\text { tract for upper abdominal symptoms } \\
\text { or reflux symptoms. Cases ( } n=240 \text {, of } \\
\text { which } 118 \text { patients with proved } \\
\text { gastro-oesophageal reflux disease } \\
\text { included). Rest with hiatus hernia and } \\
\text { no reflux oesophagitis or with } \\
\text { Barrett's oesophagus excluded. } \\
\text { Reference group ( } n=399) \text { : normal } \\
\text { endoscopy and presumed absence of } \\
\text { typical reflux symptoms }\end{array}$ & $\begin{array}{l}\text { Endoscopy of upper gastrointestinal } \\
\text { tract, } H \text { pylori testing by histology } \\
\text { (haematoxylin and eosin stain), } \\
\text { culture, quick urease test, and } \\
\text { serology (not all tests in every patient) }\end{array}$ & $\begin{array}{l}\text { H pylori prevalence in patients with } \\
\text { gastro-0esophageal reflux disease } \\
(29 \%) \text { and reference group }(51 \%)\end{array}$ & $\begin{array}{l}\text { We assumed from details that } \\
\text { patients in reference group do not } \\
\text { have reflux disease }\end{array}$ \\
\hline Koike et al $1999^{35}$ & $\begin{array}{l}\text { Case-control, } \\
\text { prospective }\end{array}$ & $\begin{array}{l}\text { Patients were self referred and } \\
\text { referred by doctor. Cases }(n=175) \text { : } \\
\text { patients with reflux oesophagitis. } \\
\text { Controls: age-sex matched, randomly } \\
\text { selected, who visited hospital, were } \\
\text { asymptomatic, and had normal } \\
\text { endoscopy results }\end{array}$ & $\begin{array}{l}\text { Endoscopy of upper gastrointestinal } \\
\text { tract. H pylori testing by histology, } \\
\text { rapid urease test, and serology. } \\
\text { Atrophic gastritis assessed by updated } \\
\text { Sydney system, and serum } \\
\text { pepsinogen measured }\end{array}$ & $\begin{array}{l}\text { H pylori prevalence in patients with } \\
\text { gastro-oesophageal reflux disease } \\
(34 \%) \text { and controls }(72 \%)\end{array}$ & \\
\hline Csendes et al $1997^{36}$ & $\begin{array}{l}\text { Case-control, } \\
\text { prospective, prevalence } \\
\text { study }\end{array}$ & $\begin{array}{l}\text { Cases ( } n=136) \text { : patients with chronic } \\
\text { gastro-oesophageal reflux disease } \\
\text { (reflux oesophagitis, negative reflux } \\
\text { disease on endoscopy) symptoms of } \\
\text { at least three years' duration. Controls } \\
\text { ( } \mathrm{n}=190) \text { ) : patients needing endoscopy, } \\
\text { none of whom had symptoms of } \\
\text { gastro-oesophageal reflux disease }\end{array}$ & $\begin{array}{l}\text { Endoscopy of upper gastrointestinal } \\
\text { tract in cases and controls, } \mathrm{H} \text { pylori } \\
\text { testing by histology, pH-metry in all } \\
\text { cases of gastro-oesophageal reflux } \\
\text { disease, no } \mathrm{pH} \text {-metry in controls }\end{array}$ & $\begin{array}{l}\text { H pylori prevalence in patients with } \\
\text { reflux oesophagitis, reflux disease } \\
\text { negative on endoscopy, Barrett's } \\
\text { oesophagus, and controls. No } \\
\text { significant difference in } H \text { pylori } \\
\text { prevalence between patients with } \\
\text { patients with reflux oesophagitis } \\
(32 \%) \text {, reflux disease negative on } \\
\text { endoscopy ( } 25 \%) \text {, and controls } \\
(29 \%) \text {. Also no difference in age and } \\
\text { sex distribution between reflux } \\
\text { patients and controls }\end{array}$ & $\begin{array}{l}\text { Exclusion of peptic ulcer not } \\
\text { clearly stated }\end{array}$ \\
\hline El-Serag et al $1999^{37}$ & $\begin{array}{l}\text { Descriptive, } \\
\text { prospective }\end{array}$ & $\begin{array}{l}\text { Patients referred for elective } \\
\text { endoscopy of upper gastrointestinal } \\
\text { tract. Cases ( } n=154 \text {, of which } 116 \\
\text { patients were included, w8 excluded } \\
\text { because of Barrett's oesophagus): all } \\
\text { patients with erosive oesophagitis. } \\
\text { Controls ( }=148 \text { ) : Patients with } \\
\text { normal endoscopy result and absence } \\
\text { of symptoms of gastro-oesophageal } \\
\text { refflux disease }\end{array}$ & $\begin{array}{c}\text { Endoscopy of upper gastrointestinal } \\
\text { tract in cases and controls, } H \text { pylori } \\
\text { testing by haematoxylin and eosin } \\
\text { stain }\end{array}$ & $\begin{array}{l}\text { H pylori prevalence in patients with } \\
\text { gastro-oesophageal reflux disease } \\
(31 \%) \text { and controls }(43 \%)\end{array}$ & $\begin{array}{c}\text { This study looked at protective } \\
\text { effect of corpus gastritis against } \\
\text { reflux oesophagitis. We excluded } \\
\text { Barrett's oesophagus from our } \\
\text { analysis }\end{array}$ \\
\hline Fallone et al $2000^{38}$ & $\begin{array}{l}\text { Descriptive, } \\
\text { prospective. }\end{array}$ & $\begin{array}{l}\text { Patients scheduled for endoscopy of } \\
\text { upper gastrointestinal tract. Cases } \\
\text { (n=327, of which } 81 \text { patients with } \\
\text { gastro-oesophageal reflux disease } \\
\text { included). Rest were classified into } \\
\text { non-ulcer disease, duodenal ulcer, } \\
\text { gastric ulcer, and therefore excluded. } \\
\text { patients with gastro-oesophageal } \\
\text { reflux disease had reflux oesophagitis } \\
\text { or negative reflux disease on } \\
\text { endoscopy. Comparator group ( } n=78) \text {. } \\
\text { patients in whom there were no } \\
\text { symptoms of gastro-oeosophageal } \\
\text { refllux disease and in whom } \\
\text { indications for endoscopy were } \\
\text { multiple. All had normal oesophagus } \\
\text { or findings unrelated to } \\
\text { gastro-oesophageal reflux disease }\end{array}$ & $\begin{array}{l}\text { Endoscopy of upper gastrointestinal } \\
\text { tract; } H \text { pylori testing by histology and } \\
\text { culture; detection of specific genes or } \\
\text { gene sequence within } H \text { pylori and } \\
\text { detection of CagA antibodies }\end{array}$ & $\begin{array}{l}\text { H pylori prevalence in patients with } \\
\text { gastro-oesophageal reflux disease } \\
(33 \%) \text { and comparator group (48\%). } \\
\text { Prevalence of CagA, CagE, vacA S1 } \\
\text { genotypes, and CagA antibody } \\
\text { determined in cases and comparator } \\
\text { group }\end{array}$ & $\begin{array}{l}\text { Some patients with reflux disease } \\
\text { negative on endoscopy but reflux } \\
\text { not proved may have been } \\
\text { included in our prevalence data. } \\
\text { This study concluded that } \\
\text { gastro-oesonhageal reflux disease } \\
\text { was associated with a significantly } \\
\text { lower rate of vacA S1 genotype } \\
\text { than in controls }\end{array}$ \\
\hline Gisbert et al $2001^{39}$ & $\begin{array}{c}\text { Descriptive, } \\
\text { prospective, prevalence }\end{array}$ & $\begin{array}{l}\text { Consecutive patients undergoing } 24 \\
\text { hour oesophageal pH monitoring in } \\
\text { motility unit because of symptoms } \\
\text { sugestive of gastro-oesophageal } \\
\text { reflux disease. Cases }(n=56 \text { ): typical } \\
\text { symptoms of gastro-oesophageal } \\
\text { reflux disease and positive pH } \\
\text { findings. Controls ( } \mathrm{n}=44 \text { ): symptoms } \\
\text { of gastro-oesophageal reflux disease } \\
\text { but negative } \mathrm{pH} \text { findings }\end{array}$ & $\begin{array}{l}\text { Endoscopy of upper gastrointestinal } \\
\text { tract, } 24 \text { hour oesophageal pH } \\
\text { monitoring and } H \text { pylori testing by } \\
\text { histology and rapid urease test }\end{array}$ & $\begin{array}{l}\text { H pylori prevalence in patients with } \\
\text { gastro-0esophageal reflux disease } \\
(57 \%) \text { and controls }(52 \%)\end{array}$ & $\begin{array}{l}\text { Comparator group may represent } \\
\text { patients with non-ulcer dyspepsia }\end{array}$ \\
\hline Goldblum et al $1998^{40}$ & $\begin{array}{l}\text { Case-control, } \\
\text { prospective }\end{array}$ & $\begin{array}{l}\text { Cases ( } n=58 \text { ): patients with classic } \\
\text { symptoms of gastro-oesophageal } \\
\text { reflux disease enrolled into study. } \\
\text { Controls (n=27): patients undergoing } \\
\text { endoscopy for reasons other than } \\
\text { symptoms of gastro-oesophageal } \\
\text { reflux disease, Barrett's oesophagus, } \\
\text { peptic ulcer disease, or dyspepsia }\end{array}$ & $\begin{array}{l}\text { Endoscopy of upper gastrointestinal } \\
\text { tract in cases and controls; } H \text { pylori } \\
\text { testing by histology (haematoxylin and } \\
\text { eosin and Giemsa stain) and serology }\end{array}$ & $\begin{array}{l}\text { H pylori prevalence in patients with } \\
\text { gastro-oesophageal reflux disease } \\
(41 \%) \text { and controls ( } 48 \%) \text {. Prevalence } \\
\text { of carditis and intestinal metaplasia of } \\
\text { cardia in cases and controls also } \\
\text { determined }\end{array}$ & $\begin{array}{l}\text { This study also concluded that } \\
\text { cardia inflammation and cardia } \\
\text { intestinal metaplasia are associated } \\
\text { with } \mathrm{H} \text { pylori infection }\end{array}$ \\
\hline $\begin{array}{l}\text { Hacklesberger et al } \\
1998^{41}\end{array}$ & $\begin{array}{l}\text { Case-control, } \\
\text { prospective }\end{array}$ & $\begin{array}{l}\text { Cases ( } 130 \text { of } 171 \text { included, } \\
\text { remaining } 41 \text { had associated peptic } \\
\text { ulcer disease): consecutive Caucasian } \\
\text { patients undergoing elective } \\
\text { endoscopy. Controls ( } \mathrm{n}=227) \text { : } \\
\text { asymptomatic volunteers or patients } \\
\text { attending for other reasons and } \\
\text { without any symptoms of } \\
\text { gastro-0esophageal reflux disease }\end{array}$ & $\begin{array}{l}\text { Endoscopy of upper gastrointestinal } \\
\text { tract in cases only. } H \text { pylori testing by } \\
\text { histology and rapid urease test in } \\
\text { cases, 13-carbon urease breath test }\end{array}$ & $\begin{array}{l}\text { H pylori prevalence in patients with } \\
\text { gastro-oesophageal reflux disease } \\
(38 \%) \text { and controls }(39 \%)\end{array}$ & $\begin{array}{l}\text { Different methods of } H \text { pylori } \\
\text { testing in cases and controls. No } \\
\text { endoscopy in controls }\end{array}$ \\
\hline Haruma et al $2000^{42}$ & $\begin{array}{l}\text { Retrospective } \\
\text { case-control }\end{array}$ & $\begin{array}{l}\text { Of } 6205 \text { patients undergoing } \\
\text { endoscopy of upper gastrointestinal } \\
\text { tract between defined periods, } 229 \\
\text { were defined as having reflux } \\
\text { oesophagitis. Of these, } 95 \text { met } \\
\text { authors' inclusion criteria. Controls } \\
\text { (n=190): healthy, asymptomatic, } \\
\text { age-sex matched selected from among } \\
608 \text { healthy individuals who had } \\
\text { undergone routine healthcare check } \\
\text { for gastric cancer }\end{array}$ & $\begin{array}{l}\text { Endoscopy of upper gastrointestinal } \\
\text { tract in cases and controls; } H \text { pylori } \\
\text { testing by Giemsa stain and serology. } \\
\text { Inflammation, atrophy, and intestinal } \\
\text { metaplasia were evaluated using } \\
\text { updated Sydney system. Serum } \\
\text { gastrin and pepsinogen concentrations } \\
\text { determined }\end{array}$ & $\begin{array}{l}\text { H pylori prevalence in patients with } \\
\text { gastro-0esophageal reflux disease } \\
(41 \%) \text { and controls }(76 \%)\end{array}$ & $\begin{array}{l}\text { The authors found significant low } \\
\text { prevalence of } H \text { pylori in patients } \\
\text { over } 60 \text { but not under } 59 \text { with } \\
\text { reflux oesophagitis, when } \\
\text { compared with age-sex matched } \\
\text { controls }\end{array}$ \\
\hline Liston et al $1996^{43}$ & $\begin{array}{c}\text { Descriptive, } \\
\text { prospective, prevalence }\end{array}$ & $\begin{array}{l}\text { Consecutive patients admitted for } \\
\text { gastroscopy recruited regardless of } \\
\text { reasons for procedure. Main reasons } \\
\text { were anaemia, reflux symptoms, and } \\
\text { epigastric pains. Cases ( } n=37) \text { : reflux } \\
\text { oesophagitis (macroscopic or } \\
\text { microscopic). Comparator group } \\
\text { (n=33): : normal endoscopy result and } \\
\text { no evidence of histological } \\
\text { oesophagitis }\end{array}$ & $\begin{array}{l}\text { Endoscopy of upper gastrointestinal } \\
\text { tract; } H \text { pylori testing by histology, } \\
\text { rapid urease test, serology, and } \\
\text { 13-carbon urease breath test }\end{array}$ & $\begin{array}{l}\text { H pylori prevalence in patients with } \\
\text { reflux oesophagitis }(76 \%) \text { and } \\
\text { comparator group }(82 \%) \text {. Patterns of } \\
\text { gastritis described in the two groups }\end{array}$ & $\begin{array}{l}\text { Although exclusion of patients } \\
\text { with peptic ulcer disease had not } \\
\text { been clearly stated, on reading the } \\
\text { paper, we assumed this to be the } \\
\text { case }\end{array}$ \\
\hline
\end{tabular}


Studies included in systematic review contd

\begin{tabular}{|c|c|c|c|c|c|}
\hline Reference & Type of study & Participants & Intervention & Outcome & Comments or conclusions \\
\hline Manes et al $1999^{44}$ & $\begin{array}{c}\text { Case-control, } \\
\text { prospective, prevalence }\end{array}$ & $\begin{array}{l}\text { Cases (105 of 202, of which } 105 \\
\text { patients with proved } \\
\text { gastro-oesophageal reflux disease } \\
\text { included): consecutive patients with } \\
\text { typical symmtoms of } \\
\text { gastro-oesophageal reflux disease } \\
\text { lasting more than six months. Peptic } \\
\text { ulcer cases excluded. Controls } \\
\text { (n=200): healthy asymptomatic blood } \\
\text { donors and patients with functional } \\
\text { non-specific abdominal problems with } \\
\text { normal endoscopy result except for } \\
\text { signs of chronic gastritis }\end{array}$ & $\begin{array}{l}\text { Endoscopy of upper gastrointestinal } \\
\text { tract in cases only. } H \text { pylori testing by } \\
\text { histology or rapid urease test in cases } \\
\text { and serology in controls }\end{array}$ & $\begin{array}{l}\text { H pylori prevalence in patients with } \\
\text { erosive reflux oesophagitis }(32 \%), \\
\text { reflux disease negative on endoscopy } \\
(62 \%) \text {, and control group ( } 40 \%) \text {. Also } \\
\text { patterns of gastritis, H pylori } \\
\text { colonisation, and dyspepsia symptoms } \\
\text { in patients with reflux disease } \\
\text { negative on endoscopy and reflux } \\
\text { oesophagitis compared }\end{array}$ & $\begin{array}{c}\text { We excluded patients with } \\
\text { Barrett's oesophagus (as stated in } \\
\text { our protocol) and also reflux } \\
\text { disease negative on endoscopy } \\
\text { (not proved to have } \\
\text { gastro-oesophageal reflux disease) } \\
\text { from our analysis. Different } \\
\text { methods of } H \text { pylori testing in } \\
\text { cases and controls, no endoscopy } \\
\text { in controls }\end{array}$ \\
\hline Mihara et al $1996^{45}$ & $\begin{array}{l}\text { Case-control, } \\
\text { prospective, prevalence }\end{array}$ & $\begin{array}{l}\text { Cases }(n=70) \text { : patients with reflux } \\
\text { oesophagitis. Controls }(n=70) \text { : age-sex } \\
\text { matched, no symptoms of } \\
\text { gastro-oesophageal reflux disease and } \\
\text { normal endoscopy result }\end{array}$ & $\begin{array}{l}\text { Endoscopy of upper gastrointestinal } \\
\text { tract, H pylori testing by Giemsa stain } \\
\text { and serology, gastritis and atrophy } \\
\text { scores, and serum pepsinogen levels }\end{array}$ & $\begin{array}{l}\text { H pylori prevalence in patients with } \\
\text { gastro-0esophageal reflux disease } \\
(37 \%) \text { and controls }(67 \%) \text {. Gastritis, } \\
\text { atrophy scores, and serum } \\
\text { pepsinogen } 1 \text {, pepsinogen } 2 \text { levels } \\
\text { and ratios in cases and controls also } \\
\text { determined }\end{array}$ & Abstract \\
\hline Newton et al $1997^{46}$ & $\begin{array}{l}\text { Case-control, } \\
\text { prospective, prevalence }\end{array}$ & $\begin{array}{l}\text { Cases ( } 83, \text { of which } 25 \text { patients with } \\
\text { proved gastro-oesophageal reflux } \\
\text { disease included): patients referred for } \\
\text { endoscopy divided into four groups. } \\
\text { (reflux oesophagitis, duodenal ulcer, } \\
\text { or both, and Barrett's oesophagus). } \\
\text { Controls (n=25): asymptomatic } \\
\text { patients with anaemia referred for } \\
\text { endoscopy }\end{array}$ & $\begin{array}{l}\text { Endoscopy of upper gastrointestinal } \\
\text { tract in cases and controls. H pylori } \\
\text { testing by histology and CLO test }\end{array}$ & $\begin{array}{l}H \text { pylori prevalence in patients with } \\
\text { gastro-0esophageal reflux disease } \\
(42 \%) \text { and controls ( } 36 \%) \text {. H pylori } \\
\text { colonisation and distribution assessed } \\
\text { in different patient groups }\end{array}$ & $\begin{array}{l}\text { We excluded patients with } \\
\text { Barrett's oesophagus, duodenal } \\
\text { ulcer, and duodenal ulcer with } \\
\text { reflux oesophagitis from our } \\
\text { analysis }\end{array}$ \\
\hline $\begin{array}{l}\text { Pieramico and Zanetti } \\
2000^{47}\end{array}$ & $\begin{array}{l}\text { Case-control, } \\
\text { prospective }\end{array}$ & $\begin{array}{l}\text { Cases (122, of which } 54 \text { patients with } \\
\text { proved gastro-oesophageal reflux } \\
\text { disease included, 68 patients with } \\
\text { negative reflux disease on endoscopy } \\
\text { excluded because reflux not proved): } \\
\text { consecutive patients referred for } \\
\text { gastro-oesophageal reflux disease } \\
\text { symptoms to endoscopy unit. } \\
\text { Controls (n=49): patients who } \\
\text { underwent endoscopy in same period } \\
\text { as cases for reasons other than } \\
\text { symptoms of gastro-oesophageal } \\
\text { reflux disease, Barrett's oesophagus, } \\
\text { active or previous peptic ulcer } \\
\text { disease, gastric or oesophageal } \\
\text { neoplasms, or dyspepsia }\end{array}$ & $\begin{array}{c}\text { Endoscopy of upper gastrointestinal } \\
\text { tract in cases and controls; } H \text { pylori } \\
\text { testing by Giemsa stain in cases and } \\
\text { controls }\end{array}$ & $\begin{array}{l}\text { H pylori prevalence in patients with } \\
\text { gastro-0esophageal reflux disease } \\
(44 \%) \text { and controls }(38 \%)\end{array}$ & $\begin{array}{c}\text { Grade } 0 \text { (reflux disease negative } \\
\text { on endoscopy, } 68 \text { patients) were } \\
\text { not proved to have } \\
\text { gastro-oesophageal reflux disease, } \\
\text { hence we excluded them from our } \\
\text { analysis }\end{array}$ \\
\hline $\begin{array}{l}\text { Schubert and Schnell } \\
1989^{48}\end{array}$ & $\begin{array}{l}\text { Descriptive, } \\
\text { prospective }\end{array}$ & $\begin{array}{l}\text { All consenting patients referred for } \\
\text { endoscopy between defined periods. } \\
\text { Cases (170, of which } 31 \text { patients with } \\
\text { proved gastro-oesophageal reflux } \\
\text { disease included). Rest were classified } \\
\text { into several diagnostic groups } \\
\text { (duodenal ulcer, gastric ulcer, } \\
\text { non-ulcer dyspepsia, gastritis, } \\
\text { duodenitis) and therefore excluded. } \\
\text { Control or comparator group (n=42): } \\
\text { patients with absence of symptoms of } \\
\text { gastro-oesophageal reflux disease and } \\
\text { normal endoscopy result }\end{array}$ & $\begin{array}{l}\text { Endoscopy of upper gastrointestinal } \\
\text { tract; } H \text { pylori testing by histology, } \\
\text { rapid urease test, and culture }\end{array}$ & $\begin{array}{l}\text { H pylori prevalence in patients with } \\
\text { gastro-oesophageal reflux disease } \\
(26 \%) \text { and comparator group }(40 \%)\end{array}$ & $\begin{array}{l}\text { Some patients with reflux disease } \\
\text { negative on endoscopy but reflux } \\
\text { not proved may have been } \\
\text { included in our prevalence data }\end{array}$ \\
\hline Shirota et al $1999^{49}$ & $\begin{array}{l}\text { Descriptive, } \\
\text { retrospective }\end{array}$ & $\begin{array}{l}\text { Random selection of cases and } \\
\text { controls from patients who underwent } \\
\text { endoscopy of upper gastrointestinal } \\
\text { tract between defined periods. Cases } \\
\text { ( } \mathrm{n}=73 \text { ): reflux oesophagitis (mild, } \\
\text { severe). Controls }(\mathrm{n}=28 \mathrm{~s}) \text { : } \text { normal } \\
\text { endoscopy result and presumed } \\
\text { absence of symptoms of } \\
\text { gastro-0esophageal reflux disease }\end{array}$ & $\begin{array}{c}\text { Endoscopy of upper gastrointestinal } \\
\text { tract, } \mathrm{H} \text { pylori testing by culture, } \\
\text { urease test, and serology, serum } \\
\text { pepsinogen levels, and oesophageal } \\
\text { manometry }\end{array}$ & $\begin{array}{l}\text { H pylori prevalence in patients with } \\
\text { gastro-oesophageal reflux disease } \\
(36 \%) \text { and controls }(61 \%) \text {. } \\
\text { Pepsinogen } 1 \text { to pepsinogen } 2 \text { ratios } \\
\text { determined to assess severity of } \\
\text { atrophic gastritis }\end{array}$ & $\begin{array}{c}\text { We assumed from details that } \\
\text { patients in control group did not } \\
\text { have symptoms of } \\
\text { gastro-oesophageal reflux disease. } \\
\text { Authors concluded that low } \\
\text { prevalence of } H \text { pylori might result } \\
\text { in milder grade of atrophic } \\
\text { gastritis and consequently } \\
\text { exacerbate reflux oesophagitis }\end{array}$ \\
\hline Vaezi et al $2000^{50}$ & $\begin{array}{l}\text { Descriptive, } \\
\text { prospective }\end{array}$ & $\begin{array}{l}\text { Patients undergoing endoscopy of } \\
\text { upper gastrointestinal tract. Based on } \\
\text { questionnaire before endoscopy and } \\
\text { endoscopy findings, patients were } \\
\text { grouped into cases: } \\
\text { gastro-oesophageal reflux disease } \\
\text { (n=108), short and long-segment } \\
\text { Barrett's oesophagus, and controls } \\
\text { (n=60). Controls had normal } \\
\text { endoscopy and no symptoms of } \\
\text { gastro-oesophageal reflux disease }\end{array}$ & $\begin{array}{l}\text { Endoscopy of upper gastrointestinal } \\
\text { tract. H pylori testing by Giemsa stain, } \\
\text { serology to determine IgG response to } \\
H \text { pylori whole cell antigen and to } \\
\text { CagA using enzyme linked } \\
\text { immunosorbent assay }\end{array}$ & $\begin{array}{l}\text { H pylori and CagA prevalence in cases } \\
\text { (gastro-0esophageal reflux disease, } \\
\text { short segment and long segment } \\
\text { Barrett's oesophagus) and controls. } \\
\text { pylori prevalence in patients with } \\
\text { gastro-oesophageal reflux disease } \\
(36 \%) \text { and controls (42\%) }\end{array}$ & $\begin{array}{c}\text { Authors concluded that CagA } \\
\text { positive } H \text { pylori strains might } \\
\text { protect against Barrett's } \\
\text { oesophagus. We excluded patients } \\
\text { with Barrett's oesophagus from } \\
\text { our analysis }\end{array}$ \\
\hline Varanasi et al $1998^{51}$ & $\begin{array}{l}\text { Descriptive, } \\
\text { retrospective }\end{array}$ & $\begin{array}{c}\text { Review of records of all patients }(>18 \\
\text { years) who had endoscopy of upper } \\
\text { gastrointestinal tract and rapid urease } \\
\text { testing. Cases ( } \mathrm{n}=54) \text { : } \\
\text { gastro-oesophageal reflux disease } \\
\text { (reflux oesophagitis or proved } \\
\text { negative reflux disease on endoscopy, } \\
\text { typical symptoms of } \\
\text { gastro-oesophageal reflux disease, } \\
\text { normal endoscopy, and histological } \\
\text { esophagitis) and Barrett's } \\
\text { oesophagus. Comparator }(n=257) \text { : } \\
\text { normal endoscopy and presumed } \\
\text { absence of symptoms of } \\
\text { gastro-oesophageal reflux disease }\end{array}$ & $\begin{array}{l}\text { Endoscopy of upper gastrointestinal } \\
\text { tract; } H \text { pylori testing by rapid urease } \\
\text { test in all, histopathology and } \\
\text { serology in some }\end{array}$ & $\begin{array}{l}\text { H pylori prevalence in patients with } \\
\text { and without gastro-oesophageal reflux } \\
\text { disease as well as stratifying for } \\
\text { presence or absence of peptic ulcer } \\
\text { disease in each group. H pylori } \\
\text { prevalence in patients with } \\
\text { gastro-oesophageal reflux disease } \\
(29 \%) \text { and controls }(34 \%)\end{array}$ & $\begin{array}{l}\text { We excluded patients with } \\
\text { Barrett's oesophagus and cases of } \\
\text { reflux oesophagitis associated with } \\
\text { peptic ulcer disease from our } \\
\text { analysis. Authors found no } \\
\text { variability of } H \text { pylori between } \\
\text { different groups of patients with } \\
\text { reflux oesophagitis }\end{array}$ \\
\hline Vicari et al $1998^{52}$ & $\begin{array}{l}\text { Prospective, } \\
\text { case-control }\end{array}$ & $\begin{array}{l}\text { Cases: patients with classic symptoms } \\
\text { of gastro-0esophageal reflux disease } \\
\text { (153, of which } 84 \text { patients included } \\
\text { and } 59 \text { with Barrett's oesophagus } \\
\text { excluded) enrolled into study. } \\
\text { Controls: patients undergoing } \\
\text { endoscopy for reasons other than } \\
\text { symptoms of gastro-osophogeal } \\
\text { reflux disease, Barrett's oesophagus, } \\
\text { peptic ulcer disease, or dyspepsia }\end{array}$ & $\begin{array}{l}\text { Endoscopy of upper gastrointestinal } \\
\text { tract in cases and controls; } H \text { pylori } \\
\text { testing by histology (haematoxylin and } \\
\text { eosin and Giemsa stain) and serology }\end{array}$ & $\begin{array}{l}\text { H pylori prevalence in patients with } \\
\text { gastro-0esophageal reflux disease } \\
\text { (36\%) and controls (46\%). CagA } \\
\text { positivity status also determined in } \\
\text { cases and controls }\end{array}$ & $\begin{array}{l}\text { Some patients with reflux disease } \\
\text { negative on endoscopy but reflux } \\
\text { not proved may have been } \\
\text { included in our prevalence data. } \\
\text { We excluded patients with } \\
\text { Barrett's oesphagus from our } \\
\text { analysis }\end{array}$ \\
\hline
\end{tabular}


Studies included in systematic review contd

\begin{tabular}{|c|c|c|c|c|c|}
\hline Reference & Type of study & Participants & Intervention & Outcome & Comments or conclusions \\
\hline Wu et al $1999^{53}$ & $\begin{array}{l}\text { Case-control, } \\
\text { prospective. }\end{array}$ & $\begin{array}{l}\text { Cases (106, of which we included } 66 \\
\text { and excluded } 40 \text { with reflux disease } \\
\text { negative on endoscopy in whom } \\
\text { diagnosis of reflux disease was not } \\
\text { proved): Patients with typical } \\
\text { symptoms of gastro-oesophageal } \\
\text { reflux disease and reflux oesophagitis. } \\
\text { Controls (n=120): absence of } \\
\text { symptoms of gastro-oesophageal } \\
\text { reflux disease, absence of dyspepsia, } \\
\text { and recruited from general medical } \\
\text { clinics and day care centres without } \\
\text { any evidence of gastrointestinal } \\
\text { disease }\end{array}$ & $\begin{array}{l}\text { Endoscopy of upper gastrointestinal } \\
\text { tract in } H \text { pylori positive cases, } H \\
\text { pylori testing by serology in cases and } \\
\text { controls, Giemsa stain for } H \text { pylori, } \\
\text { haematoxylin and eosin stain for } \\
\text { gastritis, and intensity of inflammation } \\
\text { and bacterial colonisation by the } \\
\text { updated Sydney system in } H \text { pylori } \\
\text { positive cases }\end{array}$ & $\begin{array}{l}\text { H pylori prevalence in patients with } \\
\text { gastro-oesophageal reflux disease } \\
(32 \%) \text { and controls ( } 61 \%) \text {. } \\
\text { Histological assessment of gastritis } \\
\text { and } H \text { pylori colonisation in patients } \\
\text { with gastro-oesophageal reflux } \\
\text { disease also studied }\end{array}$ & $\begin{array}{l}\text { We excluded patients with reflux } \\
\text { disease negative on endoscopy } \\
\text { from our analysis }\end{array}$ \\
\hline
\end{tabular}

0.97 (0.75 to 1.27$)$ and a test for heterogeneity of $\chi^{2}=1.8, \mathrm{df}=5, \mathrm{P}=0.88 .{ }^{10}$ The evidence for western Europe is therefore equivocal.

Consistent evidence was found for a lower prevalence of $H$ pylori infection among both North American patients with gastro-oesophageal reflux disease (odds ratio $0.70,0.55$ to 0.9 ; test for heterogeneity, $\left.\chi^{2}=0.92, \mathrm{df}=6, \mathrm{P}=0.99\right)$ and patients from the Far East with gastro-oesophageal reflux disease $(0.24,0.19$ to 0.32 and $\left.\chi^{2}=2.36, \mathrm{df}=4, \mathrm{P}=0.670\right)$. A single study from South America found a higher prevalence. ${ }^{36}$ Differences in location may explain much of the heterogeneity among the studies. Some of the remaining heterogeneity may be a product of clinical heterogeneity-for example, differences in methods of $H$ pylori testing, $\mathrm{pH}$ measurements, and endoscopic classification of oesophagitis. ${ }^{54}$

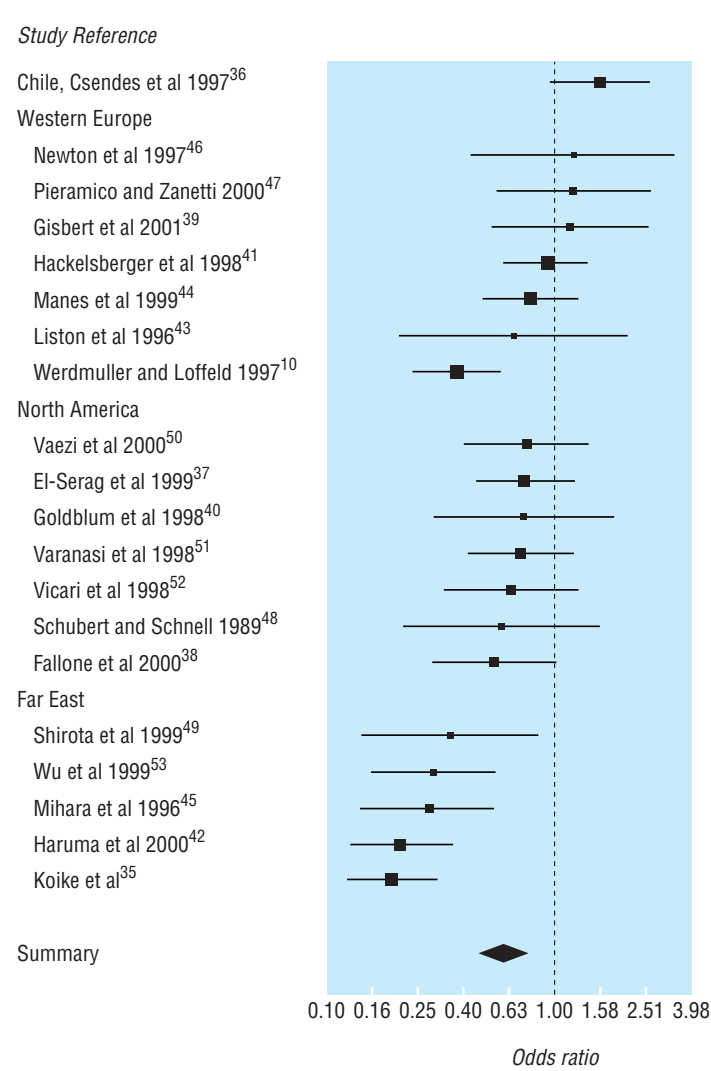

Fig 1 Odds ratios (95\% confidence intervals) for prevalence of $H$ pylori infection, grouped by geographical location. Large boxes indicate studies with small standard errors (essentially larger sample sizes) and vertical dotted line indicates no difference between groups

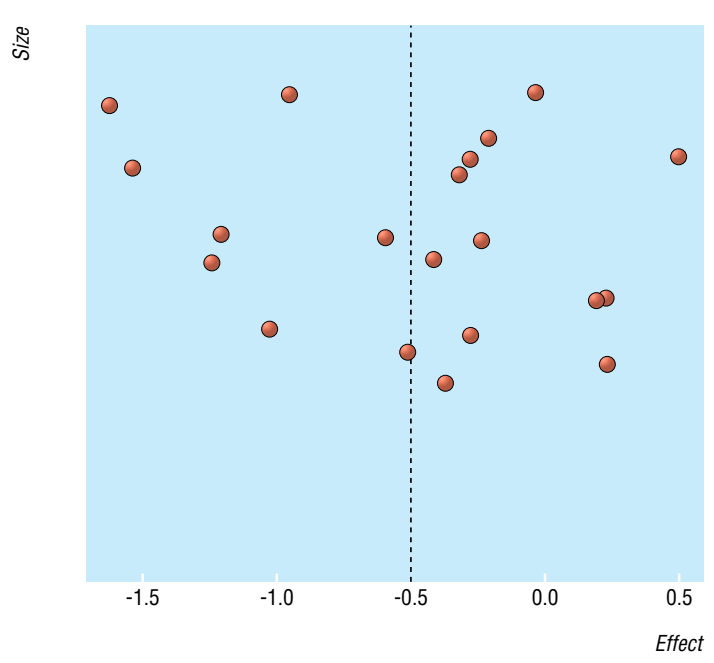

Fig 2 Size and effect of results from eligible studies of prevalence of $H$ pylori infection in patients with and without gastro-oesophageal reflux disease

\section{Discussion}

Our systematic review found a significantly lower prevalence of $H$ pylori infection among patients with gastro-oesophageal reflux disease than among those without the disease, geographical location being an important determinant. Although the results we found were based on studies with a comparator group, there were significant differences between study design (prospective or retrospective case-control, trial), study population, identification of cases and controls, inclusion and exclusion criteria, matching of cases and controls, and methods of testing for $H$ pylori. Our results therefore need to be interpreted with caution.

Most of the participants underwent endoscopy for clinical reasons and thus did not constitute a population group as such, although we discovered three community based studies. ${ }^{41}{ }^{42}{ }^{44}$ Ascertaining the prevalence of $H$ pylori thus depended on a proportion of patients who were being investigated for suspected lesions. This is unlikely to have substantially compromised our results because we excluded patients with symptoms of gastro-oesophageal reflux disease who had negative results for endoscopy or $\mathrm{pH}$ testing.

Given that there was substantial heterogeneity between the studies, we acknowledge issues about the appropriateness of reporting a pooled odds ratio. On further exploration we did find a possible difference between the Far East and North America or western Europe in prevalence of $H$ pylori infection in patients with gastro-oesophageal reflux disease; a single study 
from South America gave a higher prevalence. ${ }^{36}$ This seems to indicate that the prevalence of $H$ pylori in patients with gastro-oesophageal reflux disease is lower in countries where the prevalence of $H$ pylori in the general population is high. Reasons are unclear and may be related to dietary or genetic factors. Four studies reported a higher prevalence among patients with gastro-oesophageal reflux disease, but in only one was the difference significant. ${ }^{36}$ Reasons are uncertain but may partly be related to factors such as study design, selection of cases and controls, and method of testing for $H$ pylori. Again, presenting data as pooled estimates of odds ratios for geographical locations may give the impression of post hoc confirmatory analyses, but we strongly believe that there is a location effect evident in these data and that the prevalence has different patterns within locations.

We did not separately analyse the prevalence of $H$ pylori infection in males and females. These data were not obtainable in many studies and, when available, there was no reported difference. We excluded patients with Barrett's oesophagus because we thought that this condition merited a systematic review in its own right.

The clinical relevance of a lower prevalence of $H$ pylori in patients with gastro-oesophageal reflux disease is unclear. Some studies have shown that $H$ pylori may be protective against gastro-oesophageal reflux disease and that infected patients may have a less severe form of the disease. ${ }^{45}$ Evidence is also conflicting on the effect of $H$ pylori infection on the efficacy of proton pump inhibitors. One study found that patients with gastro-oesophageal reflux disease and $H$ pylori infection responded significantly better to proton pump inhibitors than those without the infection. ${ }^{8}$ Another trial found that patients not infected with $H$ pylori did not need higher doses of acid suppression with proton pump inhibitors to stay in remission. ${ }^{7}$ Evidence shows that $H$ pylori induces atrophic gastritis in the presence of long term acid suppression with proton pump inhibitors, and recent guidelines have advocated eradication of $H$ pylori in patients receiving long term proton pump therapy. ${ }^{65}$

We are unable to definitively comment on the benefit or possible detriment of $H$ pylori eradication in patients with gastro-oesophageal reflux disease; a further review of this is in preparation. Our findings add insight into the complex relation between $H$ pylori infection and gastro-oesophageal reflux disease. Clearly, more, well designed, prospective, large scale, case-control studies and trials are required to determine the epidemiological relation between $H$ pylori and gastro-oesophageal reflux disease and the clinical implications of this association.

Contributors: AR developed the protocol, reviewed the literature, assessed eligibility of trials, checked eligibility assessments, performed data extraction, and cowrote the manuscript. APSH developed the protocol, checked eligibility assessments, and cowrote and reviewed the manuscript. SC reviewed the literature, performed most of the eligibility assessments, and reviewed the manuscript. DW performed the statistical analyses and cowrote and reviewed the manuscript. APSH and AR will act as guarantors for the paper.

Funding: The Northern and Yorkshire NHS Executive (research and development) funded this review through a regional research fellowship to AR. Abbott Pharmaceuticals provided additional financial support. This review is a part of AR's PhD.

\section{What is already known on this topic}

The relation between $H$ pylori infection and gastro-oesophageal reflux disease is controversial

Studies on the prevalence of $H$ pylor $i$ in patients with gastro-oesophageal reflux disease have given conflicting results

Recent guidelines recommend eradication of $H$ pylori in patients requiring long term proton pump inhibitors, essentially for reflux disease

\section{What this study adds}

Despite heterogeneity between studies, the prevalence of $H$ pylor $i$ was significantly lower in patients with than without gastro-oesophageal reflux disease

Further well designed studies are required to establish the clinical relevance of the findings, particularly in eradication therapy

Competing interests: APSH is coauthor of the Maastricht 2 guidelines on the management of $H$ pylori infection; he has received research funding from Abbott Pharmaceuticals and conference travel costs and honoraria for advisory groups to several manufacturers of proton pump inhibitors over the past five years. AR has received research funding from Wyeth.

Jones R. Gastro-oesophageal reflux disease in general practice. Scand J Gastroenterol Suppl 1995;211:35-8.

Office of Health Economics. Health expenditures in the UK. London: Stationery Office, 1996.

Hosking SW, Ling TK, Chung SC, Yung MY, Cheng AF, Sung AF, et al. Duodenal ulcer healing by eradication of Helicobacter pylori withou anti-acid treatment: randomised controlled trial. Lancet 1994;343:508-10.

4 Graham DY, Yamaoka Y. H pylori and cagA. Relationships with gastric cancer, duodenal ulcer, and reflux esophagitis and its complications. Helicobacter 1998;3:145-51.

5 Richter JE, Falk GW, Vaezi MF. Helicobacter pylori and gastroesophageal reflux disease: the bug may not be all bad. Am J Gastroenterol reflux disease:

6 Malfertheiner P, Magraud F, O'Morain C, Hungin APS, Jones R, Axon A, et al. Current concepts in the management of Helicobacter pylori infection. The Maastricht 2-2000 consensus report. Aliment Pharm Ther 2002;6:167-80.

7 Schenk BE, Kuipers EJ, Klinkenberg-Knol EC, Eskes SA, Meuwissen SG Helicobacter pylori and the efficacy of omeprazole therapy for gastroesophageal reflux disease. Am J Gastroenterol 1999;94:884-7.

Holtmann G, Cain C, Malfertheiner P. Gastric Helicobacter pylori infection accelerates healing of reflux esophagitis during treatment with the proton pump inhibitor pantoprazole. Gastroenterology 1999:117:11-6.

Cheng $\mathrm{EH}$ Bermanski P Silversmith M, Valenstein P Kawanishi $\mathrm{H}$ Prevalence of Campylobacter pylori in esophagitis, gastritis, and duodePrevalence of Campylobacter pylori in esoph

10 Werdmuller BF, Loffeld RJ. Helicobacter pylori infection has no role in the pathogenesis of reflux esophagitis. Dig Dis Sci 1997;42:103-5.

11 De Koster E, Ferhat M, Deprez C, Deltenre SM. H pylori, gastric histology and gastro-esophageal reflux disease. Gastroenterology 995;108(sup$\mathrm{pl}): \mathrm{A} 81$.

12 Boixeda D, Gisbert JP, Canton R, Alvarez BI, Gil GL, Martin de AC. Is there any association between Helicobacter pylori infection and peptic esophagitis? Med Clin (Barc) 1995;105:774-7.

13 McCallum RW, De Luca V, Marshall BJ, Prakash C. Prevalence of campylobacter-like organisms in patients with gastro-esophageal reflux campylobacter-like organisms in patients with gastro-es
disease versus normals. Gastroenterology 1987;92:A1524.

14 Anonymous-French-Belgian consensus conference on adult gastrooesophageal reflux disease "diagnosis and treatment": report of a meeting held in Paris, France, on 21-22 January 1999. The jury of the consensus conference. EurJ Gastroenterol Hepatol 2000;12:129-37.

15 Dent J, Jones R, Kahrilas P, Talley NJ. Management of gastro-oesophageal reflux disease in general practice. BMJ 2001;322:344-7.

16 DeVault KR, Castell DO. Updated guidelines for the diagnosis and treatment of gastroesophageal reflux disease. The Practice Parameters Committee of the American College of Gastroenterology. Am J Gastroenterol $1999 ; 94: 1434-42$.

17 Kroes RM, Numans ME, Jones RH, de Wit NJ, Verheij TJM. Gastro-oesophageal reflux disease in primary care. Comparison and evaluation of existing national guidelines and development of uniform guidelines. Eur J Gen Pract 1999:88-97.

18 Bland JM, Altman, DG. Statistics notes: the odds. BMJ 2000;320:1468. 
19 Egger M, Davey SG, Schneider M, Inder C. Bias in meta-analysis detected by a simple graphical test. $B M J$ 1997;315:629-34.

20 DerSimonian R, Laird N. Meta-analysis in clinical trials. Controlled Clin Trials 1986;7:177-88.

21 Abbas Z, Hussain AS, Ibrahim F, Jafri SM, Shaikh H, Khan AH. Barrett's oesophagus and Helicobacter pylori. J Gastroenterol Hepatol 1995;10:331-3.

22 Oberg S, Peters JH, Nigro JJ, Theisen J, Hager JA, DeMeester SR, et al. Helicobacter pylori is not associated with the manifestations of gastroesophageal reflux disease. Arch Surg 1999;134:722-6.

23 Sekiguchi T, Shirota T, Horikoshi T. Helicobacter pylori infection and severity of reflux. Gastroenterology 1996:A755.

24 Macchiarelli R, Marzocca F, De Giorgio F, Tedone F, Bayeli PF Helicobacter pylori and gastroesophageal reflux disease. Gastroenterol Int 1998:11:194-8.

25 Velanovich V. The spectrum of Helicobacter pylori in upper gastrointestinal disease. Am Surg 1995;62:60-3.

26 Yerra LN, Bhasin DK, Panigrahi D, Vaiphei K, Sharma BC, Ray P. Prevalence of Helicobacter pylori infection in patients with reflux oesophagitis. Trop Gastroenterol 1999;20:175-7.

27 O'Connor HJ, Cunnane K. Helicobacter pylori and gastro-oesophageal reflux disease-a prospective study. Ir J Med Sci 1994;163:369-73.

28 Kuipers EJ, Klinkenberg-Knol EC, Festen HPM, Lamers BHW, Jansen JBMJ, Snel P, et al. Long-term omeprazole therapy does not affect Helicobacter pylori status in most patients. Scand J Gastroenterol 1993:28:978-80.

29 Ho KY, Kang JY. Reflux esophagitis patients in Singapore have motor and acid exposure abnormalities similar to patients in the western hemisphere. Am J Gastroenterol 1999;94:1186-91.

30 Bate CM, Tildesley G, Murray F, Dillon J, Crowe JP, Duggan SJ, et al. An effective omeprazole-based dyspepsia treatment protocol, based on clinical history, symptoms, and Helicobacter pylori status, that provides rapid symptom relief in the majority of patients. J Drug Assess 1998;1:209-25.

31 Berstad AE, Hatlebakk JG, Maartmann-Moe H, Berstad A, Brandtzag P. Helicobacter pylori gastritis and epithelial cell proliferation in patient with reflux oesophagitis after treatment with lansoprazole. Gut 1997;41:740-7.

32 Cooper BT, Gearty JC. Helicobacter pylori in Barrett's oesophagus. Gullet 1991;1:173-6.

33 Warburton-Timms VJ, Charlett A, Valori RM, Uff JS, Shepherd NA, Barr $\mathrm{H}$, et al. The significance of cagA+ Helicobacter pylori in reflux oesophagitis. Gut 2001:49:341-6.

34 Koike T, Ohara S, Sekine H, Iijima K, Abe Y, Kato K, et al. Helicobacter pylori infection inhibits reflux esophagitis by inducing atrophic gastritis. Am J Gastroenterol 1999;94:3468-72

35 Koike T, Ohara S, Sekine H, Ijima K, Kato K, Shimosegawa T, et al. Helicobacter pylori infection prevents erosive reflux oesophagitis by decreasing gastric acid secretion. Gut 2001:49:330-4.

36 Csendes A, Smok G, Cerda G, Burdiles P, Mazza D, Csendes P. Prevalence of Helicobacter pylori infection in 190 control subjects and in patients with gastroesophageal reflux, erosive esophagitis or Barrett's

37 El-Serag HB, Sonnenberg A, Jamal MM, Inadomi JM, Crooks LA, Feddersen RM. Corpus gastritis is protective against reflux oesophagitis. Gut 1999;45:181-5

38 Fallone CA, Barkun AN, Gottke MU, Best LM, Loo VG, van Zanten SV, e al. Association of Helicobacter pylori genotype with gastroesophagea reflux disease and other upper gastrointestinal diseases. Am Gastroenterol 2000;95:659-69.
39 Gisbert JP, de Pedro A, Losa C, Barreiro A, Pajares JM. Helicobacter pylori and gastroesophageal reflux disease: lack of influence of infection on twenty-four-hour esophageal $\mathrm{pH}$ monitoring and endoscopic findings. J Clin Gastroenterl 2001·22:210-4.

40 Goldblum JR, Vicari JJ, Falk GW, Rice TW, Peek RM, Easley K, et al. Inflammation and intestinal metaplasia of the gastric cardia: the role of gastroesophageal reflux and $\mathrm{H}$. pylori infection Gastroenterology 1998;114:633-9.

41 Hackelsberger A, Schultze V, Gunther T, von Arnim U, Manes G, Malfertheiner $\mathrm{P}$. The prevalence of Helicobacter pylori gastritis in patients with reflux oesophagitis: a case-control study. Eur I Gastroenterol Hepatol 1998;10:465-8.

42 Haruma K, Hamada H, Mihara M, Kamada T, Yoshihara M, Sumii K, et al. Negative association between Helicobacter pylori infection and reflux esophagitis in older patients: case-control study in Japan. Helicobacter 2000;5:24-9.

43 Liston R, Pitt MA, Banerjee AK. Reflux oesophagitis and Helicobacter pylori infection in elderly patients. Postgrad Med J 1996;72:221-3.

44 Manes G, Mosca S, Laccetti M, Lioniello M, Balzano A. Helicobacter pylori infection, pattern of gastritis, and symptoms in erosive and nonerosive gastroesophageal reflux disease. Scand I Gastroenterol 1999;34:658-62.

45 Mihara M, Haruma K, Kamada T, Kiyohira K, Goto T, Sumii M, et al. Low prevalence of Helicobacter pylori infection in patients with reflux oesophagitis. Gut 1996; 39(suppl 2):A94.

46 Newton M, Bryan R, Burnham WR, Kamm MA Evaluation of Helicobacter pylori in reflux oesophagitis and Barrett's oesophagus. Gut 1997:40:9-13

47 Pieramico O, Zanetti MV. Relationship between intestinal metaplasia of the gastro-oesophageal junction, Helicobacter pylori infection and gastro-oesophageal reflux disease: a prospective study. Dig Liver Dis 2000;32:567-72

48 Schubert TT, Schnell GA. Prevalence of Campylobacter pylori in patients undergoing upper endoscopy. Am J Gastroenterol 1989;84:637-42.

49 Shirota T, Kusano M, Kawamura O, Horikoshi T, Mori M, Sekiguchi T. Helicobacter pylori infection correlates with severity of reflux esophagitis: with manometry findinos.J Gastroenterol 1999;34:553-9.

50 Vaezi MF, Falk GW, Peek RM, Vicari IJ, Goldblum JR, Perez-Perez GI, et al. CagA-positive strains of Helicobacter pylori may protect against Barrett's esophagus. Am J Gastroenterol 2000;95:2206-11.

51 Varanasi RV, Fantry GT, Wilson KT. Decreased prevalence of Helicobacter pylori infection in gastroesophageal reflux disease. Helicobacter 1998;3:188-94.

52 Vicari JJ, Peek RM, Falk GW, Goldblum JR, Easley KA, Schnell J, et al. The seroprevalence of cagA-positive Helicobacter pylori strains in the spectrum of gastroesophageal reflux disease. Gastroenterology 1998;115:50-7.

53 Wu JC, Sung JJ, Ng EK, Go MYY, Chan WB, Chan FKL, et al. Prevalence and distribution of Helicobacter pylori in gastroesophageal reflux disease: a study from the East. Am J Gastroenterol 1999:94:1790-4.

54 Thompson SG. Why sources of heterogeneity in meta-analysis should be investigated. In: Chalmers I and Altman DG. Systematic reviews. London: BMJ Publishing Group, 1995.

55 Kuipers EJ, Lundell L, Klinkenberg-Knol EC, Havu N, Festen HP, Liedman B, et al. Atrophic gastritis and Helicobacter pylori infection in patients with reflux esophagitis treated with omeprazole or fundoplication. N Engl J Med 1996;334:1018-22

(Accepted 5 February 2003) 